\title{
PRINSIP TANGGUNG JAWAB MUTLAK PELAKU USAHA TERHADAP KETENTUAN PASAL 27 UU NO. 8 TAHUN 1999 TENTANG PERLINDUNGAN KONSUMEN
}

\author{
Fransiska Novita Eleanora
}

\begin{abstract}
Abstrak
Barang/jasa yang dikonsumsi oleh konsumen, tentunya dapat memberikan kepuasan terhadap barang/jasa yang dinikmatinya, sehingga konsumen dapat mengetahui, bahwa rasa kepuasan tersebut, memberikan manfaat dan faedah baginya. Namun, dalam mengkonsumsi barang/jasa, sering menimbulkan ketidakpuasan terhadap konsumen, dikarenakan barang/jasa itu rusak/cacat, dikemudian hari. Tetapi pelaku usaha tidak mau bertanggungjawab untuk mengganti kerugian kepada konsumen, padahal upaya perlindungan konsumen adalah prinsip perlindungan atas barang dan jasa, artinya konsumen harus mendapatkan barang dengan kualitas yang baik, sesuai dengan harga yang dibayarnya. Metode penelitian yang digunakan adalah studi kepustakaan (yuridis normatif). Tujuannya adalah Bagaimanakah prinsip tanggung jawab mutlak pelaku usaha terhadap ketentuan pasal 27 menurut UU No. 8 tahun 1999 tentang perlindungan konsumen dan bagaimakah upaya perlindungan terhadap konsumen. Hasilnya adalah pelaku usaha harus bertanggungjawab kepada konsumen, dalam Undang-Undang Perlindungan Konsumen (UUPK) No. 8 Tahun 1999 menganut prinsip tanggung jawab mutlak (strict liability), yaitu prinsip tanggung jawab yang menetapkan kesalahan tidak sebagai faktor yang menentukan.
\end{abstract}

Kata kunci ; pelaku usaha, perlindungan, konsumen 


\section{A. PENDAHULUAN}

Perlindungan konsumen merupakan bagian tak terpisahkan dari kegiatan bisnis yang sehat, dalam kegiatan bisnis yang sehat terdapat keseimbangan perlindungan hukum antara konsumen dan produsen. Tidak adanya perlindungan yang seimbang menyebabkan konsumen berada pada posisi yang lemah.

Terlebih-lebih jika produk yang dihasilkan oleh produsen merupakan jenis produk yang terbatas, produsen dapat menyalahgunakan posisinya, sehingga merugikan konsumen, upaya terpenting dalam memberikan perlindungan kepada konsumen adalah melalui peraturan perundang-undangan, dan dilakukan dengan pertimbangan yang matang.

Kerugian-kerugian yang dialami oleh produsen tersebut dapat timbul sebagai akibat dari adanya hubungan hukum perjanjian antara produsen dengan konsumen, maupun akibat dari adanya perbuatan melanggar hukum yang dilakukan produsen ${ }^{1}$

Dalam konsepsi perbuatan melanggar hukum, seseorang diberi kesempatan untuk menggugat sepanjang terpenuhi 3 (tiga) unsur, yaitu ada kesalahan (yang dilakukan pihak lain atau tergugat), ada kerugian (yang diderita si penggugat), dan ada hubungan kausalitas antara kesalahan dan kerugian itu.

Bahwa didalam hubungan tersebut, ada kerugian yang dirasakan oleh konsumen terhadap barang / jasa yang dikonsumsinya, dan para pengusaha atau pemerintah masalah yang diakibatkan akan melakukan tindakan jika ada pengaduan konsumen.

${ }^{1}$ Achmad Miru, Prinsip-prinsip Perlindungan Hukum Bagi Konsumen di Indonesia, PT. Raja Grafindo Persada, Jakarta, 2013, hal. 1 
Pada saat yang sama, para pengusaha tidak akan terdorong untuk mengambil langkah preventif, melindungi konsumen karena mengira tidak ada yang salah dengan produknya Disisi lain, masyarakat sebagai konsumen, membiarkan saja kasus / kerugian yang menimpanya, dikarenakan enggan mengajukan gugatan ganti rugi dan melaporkan keluhannya ke pihak-pihak yang berkompeten.

Kondisi tersebut dilatarbelakangi alasan beragam, alasan yang paling dominan adalah tidak mau repot dan pesimis, jika laporannya akan ditanggapi dengan baik. Kecenderungan demikian merupakan gambaran objektif budaya masyarakat kita yang permisif, yang justru semakin merugikan masyarakat itu sendiri.

Mereka juga tidak tahu persis ke mana harus mengadukan kasus yang dihadapinya dan takut pada besarnya biaya pengaduan, dan sebagian masyarakat malah takut kasus yang menimpanya akan menimbulkan kehebohan jika mereka mengadukan kasus tersebut.

Tidak adanya reaksi konsumen hingga batas tertentu jelas menguntungkan pelaku usaha, namun yang perlu dicatat pula adalah adanya pandangan sebagian besar pelaku usaha yang menilai sikap kritis masyarakat yang dianggap menganggu usahanya.

Pihak pelaku usaha kerap merespons peristiwa yang merugikan masyarakat dengan cara memojokkan konsumen dan mencari kelemahan korban. Untuk menutupi dan melepaskan tanggungjawabnya, pihak pelaku usaha sering menyatakan tindakan konsumen sebagai penghinaan, dan menuduh balik konsumen sebagai penyebab terjadinya peristiwa tersebut. $^{2}$

\footnotetext{
${ }^{2}$ NHT Siahaan, Hukum Konsumen Perlindungan Konsumen Dan TanggungJawab Produk, Panta Rei, Jakarta, 2005, hal. 8-9
} 
Atas dasar kondisi tersebut, perlu upaya pemberdayaan konsumen melalui pembentukan undang-undang yang dapat melindungi kepentingan konsumen secara integratif dan komprehensif serta dapat diterapkan secara efektif dalam masyarakat.

Piranti hukum yang melindungi konsumen tidak dimaksudkan untuk mematikan usaha para pelaku usaha, tetapi justru sebaliknya perlindungan konsumen dapat mendorong iklim berusaha yang sehat yang mendorong lahirnya perusahaan yang tangguh dalam menghadapi persaingan melalui penyediaan barang dan / atau jasa yang berkualitas $^{3}$

Berdasarkan latar belakang diatas, maka permasalahan yang dikaji oleh penulis adalah Bagaimanakah prinsip tanggung jawab pelaku usaha terhadap ketentuan pasal 27 menurut UU No. 8 tahun 1999 tentang perlindungan konsumen dan bagaimakah upaya perlindungan terhadap konsumen ??

\section{B. METODOLOGI}

\section{Pendekatan Yuridis Normatif}

Pendekatan yang dilakukan berdasarkan bahan hukum utama dengan cara menelaah teori-teori, konsep-konsep, asas-asas hukum serta peraturan perundang-undangan yang berhubungan dengan penelitian ini. Pendekatan ini dikenal pula dengan pendekatan kepustakaan, yakni dengan mempelajari buku-buku, peraturan perundangundangan dan dokumen lain yang berhubungan dengan penelitian ini.

\footnotetext{
${ }^{3}$ M. Sadar dkk, Hukum Perlindungan Konsumen di Indonesia, Akademia, Jakarta, 2012, hal. 3
} 


\section{PEMBAHASAN}

\section{a) Konsumen Dan Kedudukannya}

Sesuai dengan ketentuan Pasal 1 Angka (2) Undang-Undang Perlindungan Konsumen (UUPK), konsumen adalah setiap orang pemakai barang dan/atau jasa yang tersedia dalam masyarakat, baik bagi kepentingan diri sendiri, keluarga, orang lain maupun makhluk lain dan tidak untuk diperdagangkan

\section{Prinsip-Prinsip mengenai kedudukan konsumen dalam hubungan hukum dengan pelaku usaha ;}

\section{(i) let the buyer beware atau caveat emptor}

pelaku usaha dan konsumen adalah dua pihak yang sangat seimbang, sehingga tidak perlu ada proteksi apapun bagi si konsumen. Barang/jasa yang dikonsumsi oleh konsumen tidak mendapat akses informal yang sama, pelaku usaha tidak terbuka mengenai barang/jasa yang dijualnya, sehingga jika terjadi kerugian, maka pelaku usaha dapat berdalih, akibat kelalaian konsumen. Dalam suatu hubungan jual beli keperdataan, yang wajib berhati-hati adalah pembeli, adalah kesalahan (pembeli) jika sampai membeli dan mengkonsumsi barang-barang yang tidak layak

\section{(ii) the due care theory}

pelaku usaha mempunyai kewajiban untuk berhati-hati dalam memasyarakatkan produk, baik barang maupun jasa. Selama berhati-hati dengan produknya, ia tidak dapat dipersalahkan, maka untuk mempersalahkan 
si pelaku usaha, seseorang harus dapat membuktikan, pelaku usaha itu melanggar prinsip kehati-hatian. Ditinjau dari pembagian beban pembuktian, tampak si penggugat (konsumen) harus membentangkan bukti-bukti. Si pelaku usaha (tergugat) cukup bersikap menunggu, berdasarkan bukti-bukti dari si penggugat barulah ia membela diri

\section{(iii) the privity of contract}

pelaku usaha mempunyai kewajiban untuk melindungi konsumen, tetapi hal itu baru dapat dilakukan jika diantara mereka telah terjalin suatu hubungan kontraktual. Pelaku usaha tidak dapat disalahkan atas hal-hal diluar yang diperjanjikan. Artinya, konsumen boleh menggugat berdasarkan wanprestasi (contractual liability), ditengah minimnya peraturan perundang-undangan di bidang konsumen, sangat sulit menggugat atas dasar perbuatan melawan hukum (tortious liability). Walaupun secara yuridis sering dinyatakan, antara pelaku usaha dan konsumen berkedudukan sama, tetapi faktanya konsumen selalu didikte oleh pelaku usaha. Fenomena kontrak-kontrak standar yang banyak beredar di masyarakat merupakan petunjuk yang jelas, betapa tidak berdayanya konsumen menghadapi dominasi pelaku usaha

\section{(iv)kontrak bukan syarat}

seiring dengan bertambah kompleksnya transaksi konsumen, prinsip ini tidak mungkin lagi dipertahankan. Secara mutlak untuk mengatur hubungan antara 
pelaku usaha dan konsumen. Jadi, kontrak bukan lagi merupakan syarat untuk menetapkan eksistensi suatu hubungan hukum ${ }^{4}$

\section{b) Pelaku Usaha}

Pasal 1 angka 3 UU Nomor 8 Tahun 1999 tentang Perlindungan Konsumen menentukan bahwa "pelaku usaha adalah setiap orang perorangan atau badan usaha, baik yang berbentuk badan hukum maupun bukan badan hukum yang didirikan dan berkedudukan atau melakukan kegiatan dalam wilayah hukum negara Republik Indonesia, baik sendiri maupun bersama-sama melalui perjanjian menyelenggarakan kegiatan usaha dalam berbagai bidang ekonomi”"

Pada penjelasan undang-undang yang termasuk dalam pelaku usaha adalah perusahaan, korporasi, BUMN, koperasi, importer, pedagang, distributor, dan lain-lain. Kajian atas perlindungan terhadap konsumen tidak dapat dipisahkan dari telah terhadap hak-hak dan kewajiban produsen. Berdasarkan Directive, pengertian "produsen”meliputi :

1) Pihak yang menghasilkan produk akhir berupa barang-barang manufaktur mereka ini bertanggung jawab atas segala kerugian yang timbul dari barang yang mereka edarkan ke masyarakat, termasuk bila kerugian timbul akibat cacatnya barang yang merupakan komponen dalam proses produksinya.

2) Produsen bahan mentah atau komponen suatu produk.

\footnotetext{
${ }^{4}$ Shidarta, Hukum Perlindungan Konsumen Indonesia, PT. Gramedia Widiasarana Indonesia, Jakarta, 2004, hal.61-64

${ }^{5}$ Shofie Yusuf, Perlindungan Konsumen dan Instrumen -Instrumen Hukumnya, Citra Aditya Bakti, Bandung, 2000, hal. 54
} 
3) Siapa saja, yang dapat membubuhkan nama, merek, ataupun tanda-tanda lain pada produk menampakkan dirinya sebagai produsen dari suatu barang ${ }^{6}$

\section{c) Sengketa Konsumen}

Sengketa muncul karena adanya salah satu pihak merasa dirugikan, sehingga melakukan tuntutan kepada pihak yang lain. Begitu pula dengan sengketa konsumen yaitu sengketa yang melingkupi hukum pidana dan hukum administrasi negara karena Undang-Undang Perlindungan Konsumen (UUPK) mengatur penyelesaian sengketa bersifat ganda dan alternatif ${ }^{7}$.

Pengertian bersifat ganda di sini ialah penyelesaian sengketa dengan berbagai sistem, yakni :

(i) Penyelesaian sengketa perdata di Pengadilan (in court resolution) (Pasal 45, 46 \& 48)

(ii) Penyelesaian sengketa perdata di luar Pengadilan (out court resolution atau juga disebut alternative dispute resolution) (Pasal 45, 46, 47)

(iii)Penyelesaian perkara secara pidana (criminal court resolution) (Pasal 59, 61 s/d 63)

(iv)Penyelesaian perkara secara administratif (administratif court resolution) (Pasal 60)

\footnotetext{
${ }^{6}$ https://wisuda.unud.ac.id/pdf/1003005049-3-BAB\%20II.pdf, diunduh, Sabtu, 24 September 2016, Jam ; 5.42 wib

${ }^{7}$ Nasution, Az, Konsumen Dan Hukum, Pustaka Sinar Harapan, Jakarta, 1995, hal. 29
} 
Kepentingan antara konsumen dengan pelaku usaha juga sangat berbeda, jika ada keluhan terhadap produknya, pelaku usaha akan mengupayakan penyelesaian secara tertutup. Sementara itu konsumen berkepentingan agar penyelesaian dilakukan lewat saluran umum supaya tuntas sebagaimana dikatakan Laura Nader

\section{Perbedaan Kepentingan Pelaku Usaha}

\section{Dengan Konsumen Menurut Laura Nader}

\begin{tabular}{|c|c|}
\hline 1. Model Kepentingan Pelaku Usaha & 1. Model Kepentingan Konsumen \\
\hline $\begin{array}{l}\text { 2. Pelaku Usaha dan konsumen } \\
\text { memiliki bargaining power setara } \\
\text { keluhan konsumen harus ditangani } \\
\text { satu demi satu }\end{array}$ & $\begin{array}{l}\text { 2. Pelaku usaha mempunyai power } \\
\text { lebih besar dari konsumen keluhan } \\
\text { konsumen selayaknya dicegah } \\
\text { melalui produk yang baik }\end{array}$ \\
\hline $\begin{array}{l}\text { 3. Keluhan konsumen ditangani secara } \\
\text { tertutup (confidential) }\end{array}$ & $\begin{array}{l}\text { 3. Sistem keluhan konsumen harus } \\
\text { bersifat publik }\end{array}$ \\
\hline $\begin{array}{l}\text { 4. Informasi produk adalah milik } \\
\text { pelaku usaha }\end{array}$ & $\begin{array}{l}\text { 4. Informasi publik adalah milik publik } \\
\text { pengguna }\end{array}$ \\
\hline $\begin{array}{lll}\text { 5. } & \text { Adanya difusi dalam } \\
& \text { pertanggungjawaban korporasi }\end{array}$ & $\begin{array}{l}\text { 5. Pertanggungjawaban hukum ada pada } \\
\text { pelaku dalam korporasi }\end{array}$ \\
\hline $\begin{array}{l}\text { 6. Konsumen yang mengajukan } \\
\text { keluhan dipandang sebagai orang } \\
\text { yang tidak puas }\end{array}$ & $\begin{array}{l}\text { 6. Konsumen yang melakukan keluhan } \\
\text { semata-mata haknya sebagai pembeli }\end{array}$ \\
\hline
\end{tabular}


Namun, dengan lahirnya UUPK Tahun 1999, memberikan manfaat bagi konsumen, antara lain :

(a) Mendapatkan ganti rugi atas kerugian yang diderita

(b) Melindungi konsumen lain agar tidak mengalami kerugian yang sama

(c)Menunjukkan sikap kepada masyarakat pelaku usaha supaya lebih memperhatikan kepentingan konsumen

(d)Pengaduan dapat dijadikan tolak ukur dan titik tolak untuk memperbaiki mutu produk dan untuk memperbaiki kekurangan yang lain

(e)Menghindari persaingan yang tidak sehat ${ }^{8}$

\section{d) Prinsip Tanggung Jawab}

Terdapat 5 (lima) prinsip Pertanggungjawaban dalam Perlindungan Konsumen, yaitu:

1. Prinsip tanggung jawab berdasarkan unsur kesalahan (liability based on fault)

\footnotetext{
${ }^{8}$ NHT Siahaan, Hukum Konsumen Perlindungan Konsumen Dan TanggungJawab Produk, Panta Rei, Jakarta, 2005, hal.
} 201-204 
Berdasarkan unsur kesalahan (liability based on fault) adalah prinsip yang cukup umum berlaku dalam hukum pidana dan perdata. Dalam KUHPdt, Pasal 1365, 1366, 1367 prinsip ini dipegang secara teguh. Prinsip ini menyatakan seseorang baru dapat dimintakan pertanggungjawaban secara hukum jika ada unsur kesalahan yang dilakukannya. Dan mengharuskan terpenuhinya empat unsur pokok, yaitu a) adanya perbuatan; b) adanya unsur kesalahan; c) adanya kerugian yang diderita; d) adanya hubungan kausalitas antara kesalahan dan kerugian

2. Prinsip praduga untuk selalu bertanggung jawab (pembuktian terbalik)

Prinsip praduga selalu bertanggung jawab sampai ia dapat membuktikan ia tidak bersalah. Jadi beban pembuktian ada pada si tergugat. Tampak beban pembuktian terbalik (omkering van bewijslas) diterima dalam prinsip tersebut. UUPerlindunganKonsumen mengadopsi pembuktian terbalik ini ditegaskan dalam Pasal 19, 22, dan 23 UUPK.

3. Prinsip untuk selalu tidak bertanggung jawab (presumption of non-liability) Prinsip praduga untuk selalu tidak bertanggung jawab hanya dikenal dalam lingkup transaksi konsumen yang sangat terbatas, dan pembatasan demikian biasanya common sense dapat dibenarkan. Contoh dari penerapan prinsip ini adalah pada hukum pengangkutan. Kehilangan atau kerusakan pada bagasi kabin/bagasi tangan yang biasanya dibawa dan diawasi si penumpang (konsumen) adalah tanggung jawab dari penumpang. 
4. Prinsip tanggung jawab mutlak (strict liability)

Prinsip tanggung jawab mutlak sering diidentikkan dengan prinsip tanggung jawab absolut (absolute liability) kendati demikian ada pula para ahli yang membedakan kedua terminologi diatas. Ada pendapat yang mengatakan, strict liability adalah prinsip tanggung jawab yang menetapkan kesalahan tidak sebagai faktor yang menentukan. Namun ada pengecualianpengecualian yang memungkinkan untuk dibebaskan dari tanggung jawab, misalnya keadaan force majeure. Sebaliknya absolute liability adalah prinsip tanggung jawab tanpa kesalahan dan tidak ada pengecualiannya.

5. Prinsip tanggung jawab dengan pembatasan ((limitation of liability) prinsip tanggung jawab dengan pembatasan ia sangat disenangi oleh pelaku usaha untuk dicantumkan sebagai klausula eksonerasi dalam perjanjian standar yang dibuatnya. Dalam perjanjian cuci cetak film misalnya, ditentukan, bila film yang ingin dicuci/dicetak itu hilang atau rusak (termasuk akibat kesalahan petugas) maka si konsumen hanya dibatasi ganti kerugian sebesar sepuluh kali harga satu roll film baru. Prinsip tanggung jawab ini sangat merugikan konsumen bila ditetapkan secara sepihak oleh pelaku usaha. Dalam UUPK yang baru seharusnya pelaku usaha tidak boleh secara sepihak menentukan klausula yang merugikan konsumen, termasuk 
membatasi maksimal tanggung jawabnya, jika ada pembatasan, mutlak harus berdasarkan pada peraturan perundang-undangan yang jelas ${ }^{9}$.

\section{e) Upaya Perlindungan Konsumen}

Untuk menciptakan keseimbangan antara posisi konsumen dengan pelaku usaha, maka perlu adanya penegakan hak-hak konsumen, sebagaimana ditentukan dalam undang-undang, yang secara garis besar dapat dibagi atas 3 (tiga) bagian besar, yaitu :

a) Prinsip perlindungan kesehatan / harta konsumen

Perlindungan terhadap manusia agar kesehatannya tidak menurun/ hartanya tidak berkurang, sebagai akibat penggunaan produk. Bahkan WTO membuat persetujuan tentang pelaksanaan tindakan perlindungan kesehatan manusia, hewan dan tumbuh-tumbuhan, yang mana salah satu ketentuan yang terkandung didalamnya adalah perlindungan kesehatan manusia yang didasarkan pada bukti ilmiah, yang dimaksudkan agar suatu negara anggota tidak memperlakukan secara berlebihan terhadap produk negara lain dengan dalih tindakan perlindungan kesehatan manusia.

\section{b) Prinsip perlindungan atas barang dan harga}

Penggunaan barang dengan kualitas yang dibawah standar atau kualitas yang lebih rendah daripada nilai harga yang dibayar. Dengan perlindungan yang

\footnotetext{
${ }^{9}$ https://vanbanjarechts.wordpress.com/2013/01/01/prinsip-tanggung-jawab/, diunduh Jumat, 23 September 2016, Jam ;
} 16.31 wib 
demikian, maka konsumen tidak akan diberikan barang dengan kualitas yang lebih rendah daripada harga yang dibayarnya. Berkenaan dengan pengawasan kualitas/mutu barang, dalam WTO telah dicapai persetujuan tentang Hambatan Teknis Dalam Perdagangan, untuk menjamin agar suatu pemerintah atau instansi lain menentukan aturan teknis atau standar teknis untuk keperluan keselamatan umum, kesehatan, perlindungan terhadap kesehatan konsumen dan lingkungan hidup, atau untk keperluan lain, maka peraturan, standar dan pengujian serta sertifikasi yang dikeluarkan tidak menimbulkan rintangan yang tidak diperlukan terhadap perdagangan international.

\section{c) Prinsip penyelesaian sengketa secara patut}

Penyelesaian sengketa yang ditempuh oleh para pihak dapat berupa penyelesaian sengketa melalui pengadilan maupun di luar pengadilan, namun penyelesaian sengketa yang dihadapi oleh para pihak kadang dirasa tidak patut, lebih-lebih jika para pihak yang menghadapi sengketa tersebut memiliki kedudukan yang tidak seimbang. Ketidakseimbangan juga banyak terjadi dalam hubungan antara konsumen dengan pelaku usaha, namun ketidakseimbangan tersebut telah diusahakan untuk dihilangkan dengan lahirnya Undang-Undang Nomor 8 tahun 1999 tentang Perlindungan Konsumen. Usaha untuk menyeimbangkan kedudukan antara konsumen dengan pelaku usaha dilakukan dengan menentukan hak dan kewajiban dan tanggung jawab pelaku usaha, serta larangan pencantuman klausul baku tertentu dalam perjanjian 
Prinsip perlindungan konsumen tersebut dimaksudkan untuk mencegah timbulnya kerugiannya bagi konsumen, dan melindungi konsumen agar tetap memperoleh barang dengan kualitas yang baik, sesuai dengan harga yang dibayarkan, namun apabila tetap timbul kerugian, maka konsumen pun berhak mendapatkan penyelesaian sengketa secara patut ${ }^{10}$.

Penyelesaian sengketa secara patut adalah memperhatikan hak-hak dari konsumen, yang menikmati kualitas barang / jasa, dan mengikuti prosedur yang sesuai dan tidak memihak dalam penyelesaian kasusnya.

\section{e) Analisis}

Dalam ketentuan pasal 27 UUPK, terdapat beberapa hal yang harus dibuktikan oleh pelaku usaha untuk dapat bebas dari tanggung gugat. Pelaku usaha hanya akan dibebaskan dari tanggung gugat atas kerugian yang diderita oleh konsumen apabila :

a) Barang tersebut terbukti seharusnya tidak diedarkan atau tidak dimaksudkan untuk diedarkan

b) Cacat barang timbul dikemudian hari

${ }^{10}$ Achmad Miru, Prinsip-prinsip Perlindungan Hukum Bagi Konsumen di Indonesia, PT. Raja Grafindo Persada, Jakarta, 2013, hal. 184-210 
c) Cacat yang timbul kemudian akibat ditaatinya ketentuan mengenai kualifikasi barang

d) Kelalaian yang diakibatkan oleh konsumen

e) Lewatnya jangka waktu penuntutan 4 (empat) tahun sejak barang dibeli atau lewatnya jangka waktu yang diperjanjikan

Konsumen yang dirugikan, pada dasarnya dapat menggugat dengan adanya beban pembuktian, yaitu membuktikan adanya kesalahan pelaku usaha yang mengakibatkan kerugiannya, atau dengan kata lain, konsumen harus membuktikan :

(i) Adanya kesalahan

(ii) perbuatan melanggar hukum pelaku usaha

(iii)Adanya kerugian konsumen

(iv)Adanya hubungan kausal antara kesalahan produsen dengan kerugian konsumen $^{11}$

Dalam penerapan UUPK bahwa strict liability, didalam pasal 27, terdapat bebarapa ketentuan yang megarahkan si pelaku usaha, tidak bertanggung jawab dalam menjual barang / jasa kepada konsumen.

Apabila dicermati pasal 27 (b) UUPK tercantum "cacat barang timbul dikemudian hari”, pengertian dari kemudian hari, ini tidak jelas, bisa saja besok harinya setelah membeli barang, dan pelaku usaha tidak mau bertanggungjawab atas kerugian tersebut,

\footnotetext{
${ }^{11}$ Muhammad Abdulkadir, Hukum Perdata Indonesia, Citra Aditya Bakti, Cetakan Kedua, Bandung, 1993, hal. 31
} 
karena beranggapan bahwa tidak ada ketentuan klausula tentang barang yang dibeli tersebut.

Kerugian konsumen bisa juga terjadi dikarenakan kualitas barang tersebut tidak baik, dan pelaku usaha mengetahuinya, dan berusaha agar terjual dipasaran, padahal cacat barang tersebut sudah ada, tetapi pelaku usaha tetap menjualnya, tanpa memberitahukannya kepada konsumen.

Ayat (c), cacat yang timbul kemudian akibat ditaatinya ketentuan mengenai kualifikasi barang, seharusnya konsumen tidak disalahkan / menderita kerugian, akibat mentaati kualifasi / ketentuan aturan barang, dalam hal ini pelaku usaha hendaknya memberitahukan sebelumnya kepada konsumen, tentang hal tersebut, sehingga tidak ada unsur kerugian yang diderita konsumen, dan menurut hemat penulis ini mutlak harus diberitahukan, dan dalam hal apa, dan mengapa sampai terjadi cacat dikemudian hari.

Perlu diketahui juga kapan suatu produk mengalami cacat, dapat dibedakan atas 3 (tiga) kemungkinan, yaitu ; kesalahan produksi, cacat desain dan informasi yang tidak memadai, dan hal tersebut didasarkan dan tidak sesuai dengan harapan konsumen, anggapan tentang pengetahuan penjual terhadap adanya cacat produk, keseimbangan antara resiko dan manfaat, serta state of art $^{12}$

Ayat (e) Lewatnya jangka waktu penuntutan 4 (empat) tahun sejak barang dibeli atau lewatnya jangka waktu yang diperjanjikan, pembebasan tanggung gugat yang disebut

12 Achmad Miru, Prinsip-prinsip Perlindungan Hukum Bagi Konsumen di Indonesia, PT. Raja Grafindo Persada, Jakarta, 2013, hal. 26-27 
terakhir, yaitu karena lewatnya jangka waktu yang diperjanjikan, masih terbuka kemungkinan untuk disalahkan oleh pelaku usaha.

Karena dengan pembatasan waktu tersebut, pelaku usaha dapat membebaskan diri dari tanggung gugat dengan cara membatasi jangka waktu tanggung gugatnya, dan hal ini dapat ditetapkan pelaku usaha secara tidak wajar.

Dengan adanya bentuk kerugian-kerugian baik secara langsung ataupun tidak langsung yang diderita oleh konsumen selaku korban, sudah selayaklah penuntutan ganti rugi diberikan kepada konsumen tersebut, disinilah penerapan prinsip tanggung jawab "strict liability" artinya tanggung jawab seketika, tidak perlu dilakukan beban pembuktian, karena bentuk pertanggungjawaban disini adalah tanggungjawab seketika, tanpa mempersoalkan unsur kesalahan.

Dengan menganalisa hal tersebut diatas, maka ciri penting dari strict liability, yakni ; (i) tanggungjawab yang dibebankan adalah tidak didasarkan kesalahan, (ii) tanggungjawab timbul seketika pada saat timbulnya peristiwa, pembuktian dibebankan kepada pelaku / tergugat, (iii) adanya pengecualian tanggung jawab.

Pemidanaan terhadap pelaku usaha berdasarkan prinsip strict liability, bukan atas dasar kesalahan subjektif, tetapi mengutamakan kepentingan masyarakat banyak, dengan tujuan menjaga keseimbangan kepentingan sosial, sehingga dapat tercipta harmonisasi nilanilai sosial budaya bangsa Indonesia yang lebih mengutamakan keseimbangan antara kehidupan masyarakat dan kehidupan individu 
Barang/jasa yang dikonsumsi oleh konsumen, bisa saja selain adanya cacat, juga menimbulkan bahaya bagi konsumen tersebut, namun pelaku usaha tidak memberitahukannya, yang penting dalam pikiran si pelaku usaha, barang tersebut laku di pasaran, danp mendapat keuntungann

Ketentuan di KUHP, khsususnya di pasal 204, ayat 1 dan 2, menyebutkan :

(1) "Barang siapa menawarkan, menyerahkan atau membagi-bagikan barang yang diketahuinya membahayakan nyawa atau kesehatan orang lain, padahal sifat bahaya itu tidak diberitahu, diancam dengan pidana penjara, paling lama 15 tahun.

(2) Jika perbuatan itu mengakibatkan orang mati, yang bersalah diancam dengan pidana penjara seumur hidup atau pidana penjara selama waktu tertentu paling lam $20 \operatorname{tahun}^{13}$

Karena hak atas kenyamanan, keamanan dan keselamatan barang dan jasa, memamng mutlak menjadi hak konsumen, setidaknya hal tersebut merupakan langkah awal, jika seorang konsumen, ingin membeli barang / jasa yang diinginkannya selain kualitas dan harganya.

Untuk mewujudkan keseimbangan antara masyarakat dan individu, harus mengedepankan perlindungan dan penegakan akan hak-hak konsumen, dengan

13 NHT Siahaan, Hukum Konsumen Perlindungan Konsumen Dan TanggungJawab Produk, Panta Rei, Jakarta, 2005, hal. 192 
memperhatikan kepentingan-kepentingan para pihak berdasarkan asas itikad baik dalam perjanjian.

Hak-hak konsumen dalam menikmati barang dan / atau jasa harus diperhatikan oleh pelaku usaha, artinya konsumen berhak atas informasi yang benar terhadap menjual barang / jasa yang dikonsumsinya, dengan tujuan agar tidak muncul sengketa dikemudian hari.

\section{PENUTUP}

\section{A. Kesimpulan}


1) Penerapan prinsip tanggung jawab terhadap ketentuan Pasal 27 UUPK No. 8 Tahun 1999 adalah prinsip tanggung jawab seketika (strict liability), tanpa melihat adanya unsur kesalahan dari pelaku usaha, artinya pelaku usaha selalu bertanggung jawab terhadap barang/jasa yang dikinsumsi oleh konsumen

2) Perlindungan terhadap konsumen dengan menegakkan hak-hak konsumen, yang salah satunya adalah dengan memberikan informasi yang jelas dan benar terhadap kualitas barang dan jasa.

\section{B. Saran}

1) Pelaku usaha dalam menjual/memasarkan produk-produknya, harus memperhatikan hak-hak konsumen, kerugian yang dialami oleh konsumen, merupakan tanggungjawab pelaku usaha.

2) Perlunya disosialisakan hak-hak konsumen, sehingga jika konsumen dirugikan, akan jelas bentuk ganti rugi dan prosedur penyelesaian sengketa, dan tentunya lebih mengutamakan keadilan dn kepastian hukum. 


\section{E. DAFTAR PUSTAKA}

M. Sadar dkk, Hukum Perlindungan Konsumen di Indonesia, Akademia, Jakarta, 2012

Achmad Miru, Prinsip-prinsip Perlindungan Hukum Bagi Konsumen di Indonesia, PT. Raja Grafindo Persada, Jakarta, 2013

NHT Siahaan, Hukum Konsumen Perlindungan Konsumen Dan TanggungJawab Produk, Panta Rei, Jakarta, 2005

Nasution, Az, Konsumen Dan Hukum, Pustaka Sinar Harapan, Jakarta, 1995

Muhammad Abdulkadir, Hukum Perdata Indonesia, Citra Aditya Bakti, Cetakan Kedua, Bandung, 1993

Shofie Yusuf, Perlindungan Konsumen dan Instrumen -Instrumen Hukumnya, Citra Aditya Bakti, Bandung, 2000

Shidarta, Hukum Perlindungan Konsumen Indonesia, PT. Gramedia Widiasarana Indonesia, Jakarta, 2004

\section{KUH Pidana}

UU No. 8 Tahun 1999 tentang Perlindungan Konsumen

https://vanbanjarechts.wordpress.com/2013/01/01/prinsip-tanggung-jawab/, diunduh, Jumat, 23 September 2016, Jam ; 16.31 wib

https://wisuda.unud.ac.id/pdf/1003005049-3-BAB\%20II.pdf, diunduh, Sabtu, 24 September 2016, Jam ; 5.42 wib 